Pathways to Reform 



\section{Pathways to Reform}

CREDITS AND CONFLICT AT THE CITY UNIVERSITY OF NEW YORK

Alexandra W. Logue

PRINCETON UNIVERSITY PRESS

PRINCETON AND OXFORD 
Copyright $\odot 2017$ by Alexandra W. Logue

Requests for permission to reproduce material from this work should be sent to Permissions, Princeton University Press

Published by Princeton University Press, 41 William Street, Princeton, New Jersey 08540

In the United Kingdom: Princeton University Press, 6 Oxford Street, Woodstock, Oxfordshire OX20 1TR

press.princeton.edu

Jacket image courtesy of Alamy

Jacket design by Faceout Studio, Derek Thornton

All Rights Reserved

Library of Congress Cataloging-in-Publication Data

Names: Logue, A. W. (Alexandra W.), author.

Title: Pathways to reform : credits and conflict at the City University of New York / Alexandra W. Logue.

Description: Princeton : Princeton University Press, [2017] | Includes bibliographical references and index.

Identifiers: LCCN 2017019498 | ISBN 9780691169941 (hardback : alk. paper)

Subjects: LCSH: City University of New York-Curricula. | General education-New York

(State)-New York. | Education, Higher-New York (State)-New York.

Classification: LCC LD3835 .L64 2017 | DDC 378.747/1-dc23

LC record available at https://lccn.loc.gov/2017019498

British Library Cataloging-in-Publication Data is available

This book has been composed in Minion Pro text with Helvetica Neue Condensed Display

Printed on acid-free paper. $\infty$

Printed in the United States of America

$\begin{array}{llllllllll}10 & 9 & 8 & 7 & 6 & 5 & 4 & 3 & 2 & 1\end{array}$ 
To the memory of William G. Bowen, who inspired this work, and To CUNY students, past, present, and future 

All net royalties received by the author from sales of this book will be donated to

The City University of New York

to support undergraduate student financial aid 
